

\section{In this issue:}

\section{ACRL Continuing Education}

Courses ............. 97

Highlights of ACRL

Midwinter Meetings

Continuing Education:

CE at Case Western

Reserve ............... . 105

\section{Proposed Bylaws}

of RBMS . . . . . . . . . 107

News from the Field . . . . . . 110

People ...............113

Publications , . . . . . . . . 119

Calendar . . . ..........123

Classified Advertising
College \& Research Libraries News is published by the Association of College and Research Libraries, a division of the American Library Association, as 11 monthly (combining JulyAugust) issues, at $50 \mathrm{E}$. Huron St., Chicago, IL 60611. Annual subscription: $\$ 5$; or to members of the division, $\$ 2.50$ included in dues. Single copies and back issues, \$2 each. Second-class postage applied for at Chicago, Illinois, and at additional mailing offices (ISSN 0099-0086).

Editor. George M. Eberhart, ACRUALA, 50 E. Huron St.

Chicago, IL 60611; (312) 944-6780. President, ACRL: Millicent

D. Abell. Executive Director, ACRL: Julie Carroll Virgo.

Production and circulation office. $50 \mathrm{E}$. Huron St. Chicago,

IL 60611. Display advertising should be sent to Leona Swiech

Advertising Traffic Coordinator, ALA, at above address. Send classified ads to ACRL. Change of address and subscription orders should be addressed to College \& Research Libraries News, for receipt at the above address at least two months before the publication date of the effective issue.

Inclusion of an article or advertisement in C\&RL News does not constitute official endorsement by ACRL or ALA.

A partial list of the services indexing or abstracting the con. tents of C\&RL News includes Current Contents: Sacial \& Behavior Sciences; Current Index to Journals in Education; in. formation Science Abstracts; Library \& Information Science Abstracts; Library Literature; and Social Sciences Citation Index.

CAmerican Library Association 1981. All material in this journal subject to copyright by the American Library Associaton may be photocopied for the noncommercial purpose of scientific or educational advancement.
- Establishing and building credibility and trust;

- Consulting competencies.

III. Structuring the consulting relationship.

- Critical choices;

- Protocol:

- Phases and steps of consultation;

- Entry skills and management of client expectations.

IV. Consulting methodology.

- Range of consultative roles;

- Enhancing your competence and confidence;

- Consultative dilemmas;

- Identification and management of consulting barriers;

- Client relationships;

- Consultation model to achieve positive change;

- How to recognize action opportunities.

V. Contracting and compensation.

- Contracting for services;

- Fee structures and going rates;

- Key variables in billing;

- Inter-institutional trade-offs;

- Professional ethics.

Audience: Limited to 35 participants.

Instructor: Jim Ekendahl, Consulting Concepts, Inc., Seattle; B.A. (business administration), MLS, systems analyst, educator, trainer, and consultant to business, industry, health delivery, and educational institutions.

Location: Civic Auditorium, San Francisco.

Dates: Thursday and Friday, June 25-26, 1981, 9:00 a.m. to 5:00 p.m. (2-day course).

Cost: ACRL members $\$ 160$, non-members $\$ 180$.

\section{Planing and Procuring a Turnkey Library System}

The purpose of this workshop is to work through a process whereby an academic library manager can assess the potentials for, determine needs, and design a process for procuring a turnkey automated library system.

Participants will:

- Gain an orientation to long-range planning for automated library systems;

- Obtain an overview of automated systems and their functional capabilities;

- Acquire an understanding of steps by which one can move from the statement of library requirements through the procurement and installation of a turnkey automated library system.

Audience: For academic library personnel who potentially face, or are about to face, the task of procuring an automated library system. Limited to 35 participants.

Instructors: Rob McGee and Howard Dillon, RMG Consultants, Inc.

Location: Civic Auditorium, San Francisco.

Dates: Thursday and Friday, June 25-26, 1981, 9:00 a.m. to 5:00 p.m. (2-day course).

Cost: ACRL, members $\$ 145$, non-members $\$ 165$ 


\section{Effective Supervisory Skills}

Library managers can function effectively only if they are successful in supervising or directing the work of others. Techniques for effective supervision-such as evaluating progress, determining and scheduling completion dates, and maintaining an interim report system-are introduced in this course.

The instructor will discuss problems of freedom and interference, and when and how to direct work and offer guidance and constructive criticism. Registrants will learn the elements of effective supervision and have the opportunity-through the casestudy method-to solve supervisory dilemmas common to special libraries. Newly-appointed managers of special libraries will find this course especially helpful. Topics will include:

I. Understanding the people you supervise.

- People as a resource;

- Organizational objectives;

- Employee objectives;

- Relationship of morale and productivity;

- Management styles;

- Techniques for motivation.

II. Responsibilities of the supervisor.

- Establishing goals, objectives, and measurement criteria;

- Establishing and enforcing discipline;

- Delegation of authority/responsibility;

- Fundamental concepts in personnel administration;

- Hiring policies.

III. Techniques of supervision.

- Communications;

- Job design and analysis;

- Other factors (manpower ceilings, freezes, and purchased services; the library as the personnel dumping ground; dealing with unions, civil service, and tenure constraints; and layoffs and attrition).

Audience: People who manage or are managed. Limited to 35 participants.

Instructor: Herbert S. White, dean and professor, Graduate School of Library and Information Science, Indiana University; formerly senior vice president of ISI, executive director of the NASA Scientific and Technical Information Facility, and Project Manager of the IBM Corporate Technical Center.

Location: Civic Auditorium, San Francisco.

Date: Friday, June 26, 1981, 9:00 a.m. to 5:00 p.m.

Cost: ACRL members $\$ 75$, non-members $\$ 95$.

\section{Career Planning for the ACADEMIC LIBRARIAN}

Participants in this workshop will review factors which influence career development; explore alternative methods of career planning; begin to apply career planning techniques which help one determine career goals and objectives; review methods for putting career plans into effect; and discuss obstacles to implementing plans.

Emphasis will be on career planning and development in the academic library setting.

Following the workshop each participant should be able to:

- Explain many of the factors which influence career planning and development;

- Assess their own career needs, desires, and abilities;

- Assess their own career situation, and delineate opportunities and limitations;

- Determine personal career goals and objectives;

- Design and implement a career development plan;

- Evaluate career plans on a periodic basis and modify those plans as needed.

Audience: For academic librarians with two or more years of library experience. Registration will be limited to 36 to allow for group discussion and individual and small group exercises.

Instructor: Keith W. Russell is currently a program associate with the Council on Library Resources, Washington, D.C. For several years he has been giving workshops and tutorials on careerrelated topics.

Location: Civic Auditorium, San Francisco.

Date: Friday, June 26, 1981, 9:00 a.m. to 5:00 p.m.

Cost: ACRL members $\$ 75$, non-members $\$ 95$.

\section{Basic Archives Management FOR LIBRARIES}

This course is co-sponsored by the Society of American Archivists. It will inform libraries about basic archival functions so that they will gain a better understanding of the work they do or supervise. Participation will enable library supervisors and administrators to make sound operating, budgetary, and personnel decisions in departments with archival and manuscript holdings.

Following the course each participant should be able to:

- Describe the basic archival functions and their relationship to each other;

- Convey an appreciation of the uniqueness of archive and manuscript materials and how they should be organized, cared for, and accessed;

- Provide opportunities for first-hand acquaintance with archival problems through case studies, discussions, and practicums.

Topics will include:

- Introductory session which addresses differences between archives management and librarianship; differences in handling archival and library materials; and archival terminology;

- Appraisal of archival materials;

- Acquisitions and the development of a collections policy; 
- Arrangement and description;

- Reference and access;

- Repository management: security, outreach programs, establishing priorities, ethics, and professional concerns.

Audience: For librarians with little or no formal archival education. Participants may have had some on-the-job experience with archives or manuscripts. They may work with archival holdings as one part of their job or they may supervise someone who has that responsibility.

Instructors: David Horn, university archivist, DePauw University, Greencastle, Indiana; and Megan Floyd Desnoyers, Kennedy Library, National Archives, Boston.

Location: Sheraton-Palace Hotel, San Francisco. Dates: Wednesday, June 24, to Friday, June 26, 1981, 9:00 a.m. to 5:00 p.m. (3-day course).

Cost: ACRL members \$195, non-members \$220.

\section{Premises, Problems, Promises}

This second preconference of ACRL's Bibliographic Instruction Section offers participants a variety of formal and informal opportunities for meeting, working, and sharing ideas with fellow instruction librarians. The preconference will begin with a wine and cheese reception on Wednesday evening, June 24, and will be followed on June 25-26 with a keynote address and six workshops. Scheduling has been arranged to allow for each registrant to hear two of the six workshop presentations.

The workshops are intended to provide participants with a rewarding blend of theory and practice. Informal discussion opportunities will be available through a series of "Cracker Barrel" discussions. These smaller sessions will address such current issues as Education for Bibliographic Instruction, Career Development for Bibliographic Instruction Librarians, Burnout, The State of the Literature, and Writing and Research for Bibliographic Instruction. Simultaneously with the workshops a "think tank" will brainstorm the issues, concerns, and options facing instruction librarians in the coming decade and will report its deliberations in a panel presentation at the closing general session.

Audience: Librarians working with or interested in bibliographic instruction. Limited to 300 people.

Speakers:

- Fran Hopkins, Temple University-Keynote Address

- Joyce Hagen, California State University at Northridge- "Classroom Planning and Classroom Dynamics"

- Mary Reichel and Mary Ann Ramey, Georgia State University, and Gemma Devinney, SUNY Buffalo-" Conceptual Frameworks for Bibliographic Instruction Presentations"

- Cerise Oberman-Soroka, College of Charleston, and Mark Schlesinger, University of Massachusetts-"Cognitive Learning in Bibliographic Instruction"

- Janice Koyama, University of California at
Berkeley_-"Program Coordination"

- Bessie Hahn, Brandeis University-"Public Relations and the Politics of Bibliographic Instruction"

- Mignon Adams, SUNY Oswego--"Evaluation Tools and Tactics"

Location: University of San Francisco.

Dates: Wednesday, June 24, 6:00 p.m., through Friday, June 26, 6:00 p.m.

Cost: ACRL members $\$ 115$, non-members $\$ 140$. Fee includes dormitory housing June 24-25 and all meals from Thursday breakfast through Friday lunch. Pre-registration ends May 15. Late registrants will be accepted on a space available basis subject to a $\$ 15$ late registration fee.

\section{The IMPaCt of THE New TeChNOLOGY on LRC Programs}

The first ACRL Community and Junior College Libraries Section preconference to be held in many years will provide information on newer technologies which affect the delivery of learning resources services. It will also be a forum for the exchange of information on programs now in operation throughout the country. Small groups will meet to discuss non-traditional library catalogs, automated circulation systems, collection development and acquisitions, and commercially developed as well as "do-ityourself" systems. Included in each discussion will be ways in which implementation can be achieved either in segments or in cooperative efforts with other institutions. In addition to the presentations and discussions there will be a visit to the Mission College LRC where a tour will focus on the open learning concept at the college. A number of hardware vendors from the Silicon Valley will be available to discuss their products. A tour and reception at the Paul Masson Winery will be held following the visit to Mission College.

Audience: Community and junior college librarians and learning resource center personnel involved in or interested in the application of new technology in learning resource centers. Limited to 200 people.

Speakers:

- Ruth Person, Catholic University-" New Technology-The Human Impact"

- Ron Van Fleet, Brodart, Inc.--"The NonTraditional Catalogs-Online or COM"

- West Valley California Joint Community College District staff-"Automated Circulation Systems"

- Marcia Romansky, Baker and Taylor Co."Collection Development and Acquisitions Programs"

- Ronald Miller, CLASS-“Commercially Available Systems: Do-It-Yourself Programs"

- Jeannette Mosey, OCLC-“Cooperative Programming (Networks)"

- Joseph Mathews, Joseph Mathews \& Associates- "Which Comes First: The Computer or the Program?" and "Home Computer Ap- 


\title{
REGISTRATION FORM
}

\author{
PRECONFERENCES AND \\ CONTINUING EDUCATION COURSES
}

PLEASE PRINT

Name

LAST

FIRST

Phone (office) ( )

Mailing address

$$
\text { STREET }
$$

CITY

STATE

ZIP

Institutional affiliation (to appear on badge)

PLEASE CIRCLE THE APPROPRIATE DOLLAR AMOUNT

FOR THE COURSE OF YOUR CHOICE

Course

CE 1 Librarian as Consultant (2 days)

CE 2 Planning and Procuring a Turnkey Library System (2 days)

CE 3 Effective Supervisory Skills (1 day)

CE 4 Career Planning for the Academic Librarian (1 day)

CE 5 Basic Archives Management for Libraries (3 days)

PC 1 Views and Approaches to Bibliographic Instruction (includes housing and meals) (21/2 days)
ACRL Member Non-member

$\$ 160$

$\$ 180$

145

75

165

75

95

195

220

115

140

PC 2 The Impact of the New Technology on LRC Programs ( 2 days)

PC 3 The Collection Builders: Booksellers, Book Collectors, Librarians ( $31 \frac{1}{2}$ days)

*Late registration fee

15

\section{ENTER TOTAL AMOUNT ENCLOSED}

*Fee for registration after May 15 (applies to PC 1-3 only).

CONFIRMATION: Written confirmations will be made.

CANCELLATIONS: Written notice of cancellations received by June 1 will be honored subject to a $\$ 20$ cancellation charge. No refunds for cancellations received after June 1.

Mail this form and your check to:

REGISTER EARLY
Association of College and Research Libraries 50 E. Huron St.

Chicago, IL 60611

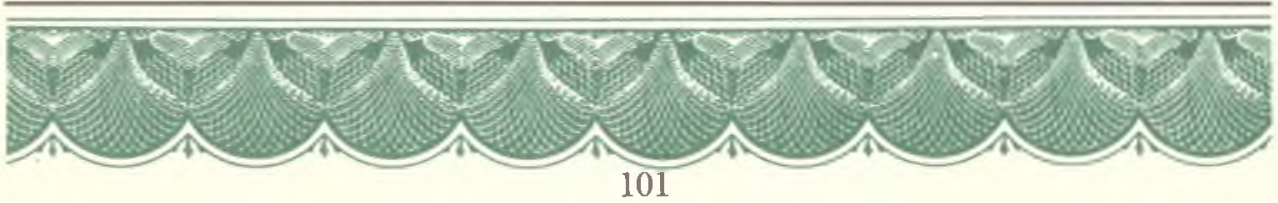


"For workers in the field, whether librarians, scholars, teachers, writers or illustrators, the Hodges-Steinfirst revision and enlargement is an absolute necessity. The 'outlines' add up to a remarkably concise summary of the history of children's literature: invaluable."-CLIFTON FADIMAN

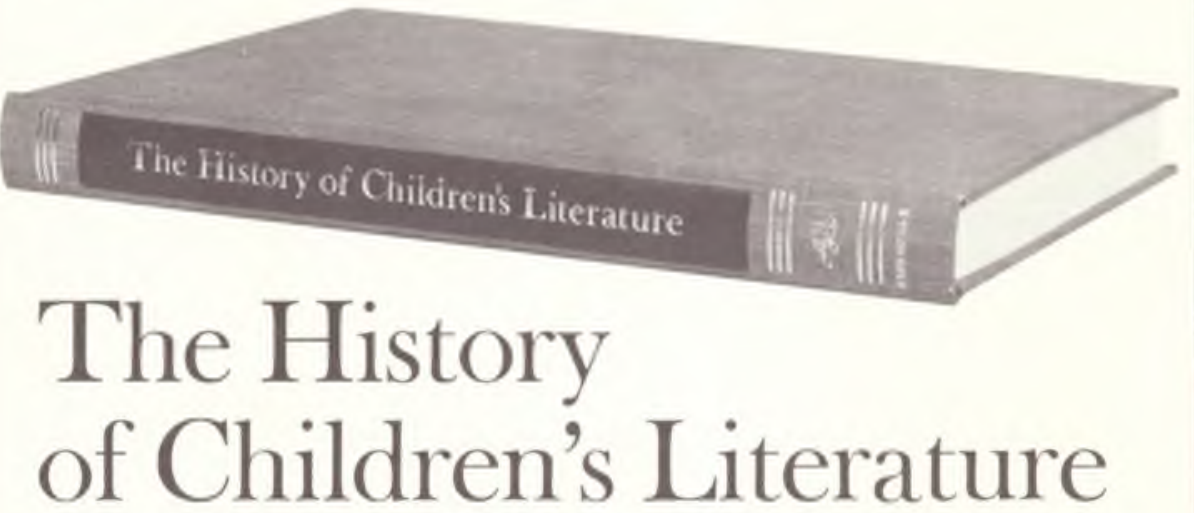

A Syllabus with Selected Bibliographies, 2nd edition

Elva S. Smith; revised and enlarged by

Margaret Hodges and Susan Steinfirst

This landwork work presents by chapters in outline form the principal developments in the history of children's literature and names the authors and titles that characterize these developments. Each outline is followed by an annotated list of secondary sources that explore the specific aspects of the period. Thus, this work serves as a handy guide to the field of children's literature and the critical writings about it.

The second edition extends the outlines and reevaluates the critical writings to include those published since the previons edition and felt to possess continuing usefulness. Each chapter is prefaced by a headnote that summarizes the salient features of the period. Hodges and Steinfirst then improve Smith's concept of a guide to research in children's literature by increasing the detail in the outlines. In this way, the usefulness of the work for suggesting topics for investigation is enhanced.

304 pages Cloth LC 79-28323 010 ISBN 0-8389.0286-3 (1980) $\$ 40.00$

Order Department

AMERICAN LIBRARY ASSOCIATION

50 East Huron Street, Chicago, Illinois 60611 
plications for Learning Resource Programs"

- J. O. Wallace, San Antonio College- "Reference and Data Base Services"

- Chip Harris, Coastline Community College"Cable TV"

Location: Sheraton Palace Hotel, San Francisco.

Dates: Thursday, June 25, 1:00 p.m., to Friday, June 26, 4:30 p.m.

Cost: ACRL members $\$ 95$, non-members $\$ 115$. Pre-registration ends May 15. Later registration will be accepted on a space available basis subject to a $\$ 15$ late registration fee.

\section{The Collection Builders}

The program for the 22d ACRL Rare Books and Manuscripts Section preconference will focus on the roles played in the past and present by each of the three major types of builders of library collections. In addition to formal papers to be delivered by prominent people in each area (booksellers, book collectors, and librarians), the program will take advantage of the book collection resources of the San Francisco Bay area. One part of the program will include a reception at Stanford University's newly completed Rare Books Room. Receptions will also be hosted by both the Northern California Chapter of the Antiquarian Booksellers Association of America and the Wine Museum of San Francisco where an exhibit of rare wine history books and manuscripts will be on display.

Audience: Rare book and special collections librarians. Limited to 200 people.

Speakers:

- Ian Willison, British Library-"Panizzi, the British Museum Library, the Antiquarian Book-trade, and Collection Development in Large Institutions"

- Richard G. Landon, University of Toronto"Management of Collection Development at the Present Time, Special Collections in State-Supported Institutions"

- Frederick R. Goff, Library of Congress-"Lessing Rosenwald and the Gift to the Nation"

- Bernard M. Rosenthal, bookseller-"Antiquarian Booktrade since the Second World War"

- Alexandra Mason, University of Kansas"Robert Vosper and Franklin Murphy: Support of Special Collections at Lawrence and I os Angeles"

- William R. Cagle, Indiana University-"J. K. Lilly, David A. Randall, the Lilly Library and Indiana University"

- Robert Rosenthal, University of Chicago"Chicago Libraries, Book Collectors, and the Booktrade: A Regional Experience"

- Herman W. Liebert, Yale University-“"The Beineckes"

- James D. Hart, University of California, and Jacob I. Zeitlin, bookseller-"Booksellers, Book Collectors, Librarians, and the Legacy to California"
In addition to the formal presentations, there will be six seminars coordinated by the RBMS Continuing Education Committee.

Location: Golden Gateway Holiday Inn, San Francisco.

Dates: Tuesday, June 23, 3:00 p.m., to Friday, June $26,3: 30$ p.m.

Cost: ACRL members \$140, non-members $\$ 180$. Pre-registration ends May 15. Late registration will be accepted on a space available basis subject to a $\$ 15$ late registration fee.

\section{INTERNATIONAL CONFERENCE OF SILAVIC LIBRARIANS}

On September 29-October 4, 1980, nearly sixty librarians and information specialists from thirteen countries met at Garmisch-Partenkirchen, West Germany, during the Second World Congress for Soviet and East European Studies, to hold the First International Conference of Slavic Librarians, entitled "Access to Resources in the 80 "s."

A highlight of the conference was the first session, a panel on documentation and information aimed at both information specialists and scholars in the disciplines. Informal working sessions dealt with the orientation of users by means of written guides and courses; reprints and microforms in the Slavic and East European field; and problems related to the use of archives in the East and West. More formal presentations were made by representatives of Western countries in two sessions devoted to information centers and bibliographic control concerning Eastern Europe. The concluding session opened with a report by a former Soviet librarian on problems with Soviet methods of compiling reference works.

The conference played an important role in helping to create an international network of librarians and information specialists in a critical subject field. Proceedings of the conference will be published as a separate volume within the general Congress proceedings.

The absence of East European participants was regrettable, but it is hoped they will attend the next conference planned for 1985 in the United States in conjunction with the Third World Congress for Soviet and East European Studies. Suggestions for discussion in 1985 include problems concerning interlibrary loans, problems in transliteration, cooperation in the acquisition of ephemera, additional information about libraries maintained by emigrants, and the demonstration of computer applications in the field. For more information about Garmisch and plans for the future, contact Marianna Tax Choldin, Slavic and East European Department, 225 Library, 1408 W. Gregory Drive, University of Illinois, Urbana, IL 61801. 